\title{
Pengembangan Metode Sekolah Minggu MEBIG Jepang bagi Anak Usia 3-5 Tahun Dalam Menunjang Minat Beribadah
}

Oleh:

\section{ASTRI}

\section{MAHASISWA INSTITUT AGAMA KRISTEN NEGERI (IAKN) TORAJA}

\author{
Jalan Poros Makale-Makassar Km 11,5 Buntu Tangti, Mengkendek
}

Kabupaten Tana Toraja, Sulawesi Selatan 91871

Email: allingastrid12@gmail.com

\begin{abstract}
Abstrak:
Kurangnya minat anak-anak untuk mengikuti ibadah sekolah minggu salah satu penyebabnya adalah pemilihan meode pembelajaran yang kurag tepat dengan kebutuhan perkembangan usia mereka. Di usia 3-5 tahun anak kebutuhan anak masih sangat membutuhkan permainan, sehingga dalam ibadah sekolah minggu, pembimbing bisa menerapkan metode Mebig Jepang dimana Mebig adalah pelayanan yang mengedepankan konsep memory, bible dan game. Game atau permainan menjadi fokus dalam pendidikan anak atau sekolah minggu Mebig. Dengan memperhatikan kebutuhan perkembangan anak guru sekolah minggu bisa memilih metode yang tepat, dengan penerapan metode Mebig Jepang ini diharapkan dapat meningkatkan minat anak-anak untuk beribadah serta menumbuhkan kreativitas guru sekolah minggu.
\end{abstract}

Kata kunci: Pelayanan Sekolah Minggu, Model MEBIG Jepang, Anak usia 3-5 tahun. 


\section{Pendahuluan}

Globalisasi dunia beranjak kepada era yang dikenal dengan sebutan era Revolusi Industri 4.0. Revolusi Industri 4.0 merupakan perubahan industri ke-4, hal ini menyebabkan banyak perubahan yaitu optimasi robot dan mesin dalam setiap dunia industri dengan sistem konektivitas dan digitalisasinya. ${ }^{1}$ Maka tidak dapat disangkali perkembangan di era revolusi industri 4.0 berdampak pula pada kehidupan maupun pendidikan bangsa Indonesia. Sehingga perlunya memikirkan strategi ataupun metode yang cocok bagi generasi 4.0 dalam rangka menyiapkan generasi yang baik dan berkualitas.

Dampak dari revolusi 4.0 akan berdampak pada sistem pendidikan baik itu bagi pendidikan formal dan pendidikan non formal, salah satu pendidikan non formal bagi kalangan Kristen adalah sekolah minggu, sekolah minggu adalah suatu bentuk pendidikan non formal yang merupakan wabah bagi gereja untuk mempersipakan dan memperlangkapi anak-anak untuk mengenal Yesus Kristus secara pribadi. ${ }^{2}$ Pada kenyatannya guru sekolah minggu banyak mengalami kesulitan dalam menyampaikan Firman Tuhan termasuk dalam pemilihan metode ataupun strategi yang tepat untuk usia anak-anak khususnya bagi anak usia 3-5 tahun.

Jika diamati, kerinduan anak-anak untuk datang ke sekolah minggu kian lama cenderung kian menurun. Ada banyak hal yang menyebabkan minat anak-anak datang ke Gereja dalam hal ini tentu sekolah minggu. Salah satunya adalah penggunaan metode yang kurang tepat atau kurang bervariasi atau bahkan metode yang kurang tepat dengan usia anakanak. Pemilihan metode bisa jadi salah satu penyebab dari kurangnya minat anak-anak dalam ibadah Sekolah Minggu yang mengakibatkan anak-anak merasa bosan dan lebih memilih untuk melakukan kegiatan lain. Melihat keadaan tersebut maka guru sekolah minggu harus mengembangkan diri agar kegiatan belajar mengajar menjadi kretaif dan menarik buat anakanak tetapi juga harus efektif.

Guru sekolah minggu yang kreatif dan menarik tidak hanya mengajarkan pengetahuan kepada anak-anak tetapi bagaimana guru sekolah minggu membuat mereka merasa nyaman dan bahagia dalam ibadah, sebagai guru bukan hanya mengutamakan pengetahuan kepada

\footnotetext{
${ }^{1} 1$ Venti Eka Satya, “Strategi Indonesia Menghadapi Industri 4.0. ”Jurnal Info Singkat: Kajian Singkat Terhadap Isu Aktual dan Strategis. Vol , No 09.(Mei, 2018) 19-20.

${ }^{2}$ 1http://Alkitab. sabda. org/, 13 maret 2017
} 
anak tetapi lebih mengutamakan kecintaannya melihat kegembiraan anak-anak. Ada banyak metode yang dapat dipelajari guru sekolah minggu. Oleh karena itu guru sekolah minggu perlu metode yang kreatif dan sesuai dengan usia anak-anak uisa 3-5 tahun salah satunya adalah metode MEBIG Jepang dalam rangka menumbuhkan minat beribadah mereka yang dapat membawa anak-anak dalam rangka pengenalan akan Yesus Kristus.

\section{Rumusan Masalah}

Penelitian ini beranjak dari fokus masalah, kurangnya kreativitas guru sekolah minggu yang mengakibatkan kurangnya minat beribadah anak-anak. Sehingga muncullah suatu rumusan bagaimana metode sekolah minggu MEBIG Jepang dalam menunjang minat beribadah anak-anak usia 3-5 tahun.

\section{Tujuan}

Penelitian ini bertujuan untuk mengetahui bagaimana metode sekolah minggu MEBIG Jepang dalam menunjang minat beribadah anak usia 3-5 tahun.

\section{Manfaat}

Manfaat dari penelitian ini adalah: pertama guru sekolah minggu mengerti dan menyadari pentingnya kreativitas dan kesesuaian metode dengan usia anak-anak, kedua memberikan gambaran bagi gereja untuk lebih memberi perhatian dan pelayanan sekolah minggu, ketiga, sebagai arahan untuk setiap pelayan, hamba Tuhan dalam melakukan pelayanan bagi anak-anak usia 3-5 tahun dalam menunjang minat beribadah. 


\section{Pembahasan}

\section{Pelayanan Sekolah Minggu}

Gereja sebagai pusat pendidikan Kristen setelah keluarga yang bertanggung jawab melaksanakan pendidikan Kristen seutuhnya bagi seluruh jemaat baik terhadap orang dewasa maupun terhadap anak-anak. Sekolah minggu merupakan salah satu bentuk layanan pendidikan Kristen yang dilaksankan oleh gereja dalam rangka pembinaan kerohanian anak agar dapat mengenal Yesus Kristus sebagai Tuhan dan Juruselamatnya. Harry M. Pilland berkata sekolah minggu merupakan wadah pelayanan yang penting dalam menjangkau orang orang bagi Kristus dan mengembangkan mereka menjadi seperti Dia. ${ }^{3}$ Sehingga pentingnya bagi gereja memperhatikan pelayanan kepada anak-anak dengan membimbing para guru sekolah minggu, pentingnya mengajar anak adalah mengajar adalah perintah Tuhan (ulangan 6:7), menumbuhkan dasar iman yang teguh, anak membutuhkan Juruselamat, anak-anak adalah karunia, anak-anak sangat berharga bagi Allah (1 Samuel 20:42, Ezra 8:21).

Mengacu pada perkataan Tuhan Yesus Kristus sendiri: "Biarkanlah anak-anak itu, janganlah engkau menghalang-halangi mereka datang kepada-Ku, sebab orang-orang yang seperti itulah yang empunya kerajaan sorga" Matius 19:14. Didalam perkataan Tuhan Yesus itu ada beberapa pengajaran bahwa, Tuhan Yesus sangat mengasihi anak-anak dan menginginkan anak-anak untuk rindu datang kepadaNya. Tuhan Yesus memerintahkan agar jangan ada seorangpun yang melarang anak-anak untuk datang kepadaNya dan mempersulit anak-anak dalam mengenal diriNya. Tuhan Yesus mengasihi anak-anak tanpa membedakannya dari orang dewasa. Di dalam pengajajaran Yesus Kristus itu Ia memerintahkan agar orang dewasa menuntun anak-anak untuk datang kepada-Nya. ${ }^{4}$ Sekolah minggu merupakan salah satu wujud pelayanan khusus di antara anak-anak dengan tujuan membawa mereka untuk mengenal dan menerima Yesus Kristus sebagai Tuhan dan Juruselamat mereka secara pribadi.

Dalam lingkup Gereja Toraja, anggota SMGT terdiri dari anak sekolah minggu gereja toraja usia 0-15 tahun dan pengurus sekolah minggu. Dalam pengkategoriannya, SMGT terdiri dari kelas bayi (0-2 tahun), kelas balita (3-5 tahun), kelas anak kecil (6-8 tahun), kelas

\footnotetext{
${ }^{3}$ Harry M. Pilland, Perkembangan Gereja Dan Penginjilan Melalui Sekolah Minggu (Bandung:Lembaga Literatur Baptis, 1984), 7.

${ }^{4}$ Resource, Jurnal Pelita Zaman, Vol 4 No.1 tahun 1989(hakikat sekolah minggu untuk anak)
} 
anak besar (9-11 tahun) dan kelas anak remaja (12-15) tahun. ${ }^{5}$ Anak umur 3-5 tahun disebut pula kelas balita atau kelas indria, kebanyakan kasus guru sekolah minggu kewalahan menghadapi anak-anak di usia ini karena anak di usia ini adalah masa dimana permainan adalah kebutuhan utama bagi mereka, oleh karena itu perlunya kreatifitas dan penerapan metode yang tepat bagi usia mereka. Guru sekolah minggu yang kreatif dan menyenangkan selalu dinanti-nantikan oleh anak-anak dan gruu sekolah minggu hendaknya mempunyai kecintaan terhadap anak-anak sekolah minggu.

\section{Metode Sekolah Minggu MEBIG Jepang}

Mebig Jepang adalah pelayanan sekolah minggu secara kreatif di jepang yang memfokuskan pada pemuridan. Mazmur 127:3-4 "Sesungguhnya anak-anak lelaki adalah milik pusaka dari pada Tuhan, dan buah kandungan adalah suatu upah. Seperti anak panah di tangan Pahlawan, demikianlah anak-anak pada masa muda”. Mebig Jepang memaknai bahwa anak-anak adalah milik pusaka, upah yaitu pelayanan yang murni kepada anak dan pada akhirnya anak-anak kan menjadi senjata atau kekuatan bagi orang dewasa. ${ }^{6}$

Mebig adalah pelayanan yang mengedepankan konsep memory, bible dan game. Game atau permainan menjadi fokus dalam pendidikan anak atau sekolah minggu Mebig. ${ }^{7}$ Pentingnya bermain bagi anak, dunia anak adalah dunia bermain. diamana pun mereka berada, sendiri atau dalam kelompok, aspek bermain selalu menonjol dan digemari. Oleh sebab itu guru Sekolah Minggu hendaknya mampu mengakomodasi kebutuhan tumbuh kembang anak yang dipadukan dengan aspek ibadah dan proses belajar melalui Mebig Jepang ini. Dampak dalam bermain akan menimbulkan stimulus serta minat anak dalam beribadah sebagaimana Amsal 17:22 "Hati yang gembira adalah obat yang manjur, tetapi semangat yang patah mengeringkan tulang”.

Bermain merupakan dasar sarana pentingya pertumbuhan otak anak. Mebig mendasari sekolah minggu dengan menggunakan permainan untuk memaksimalkan pertumbuhan dan

\footnotetext{
${ }^{5}$ Daniel Fajar Panuntun et al., Model ibadah Sekolah Minggu Kreatif-Interaktif Bagi Generasi Alfa Di Gereja Toraja, "BIA: Jurnal Teologi dan Pendidikan Kristen Kobtekstual 2, no.2 (2019)

${ }^{6}$ Teppei Yama, "Pemuridan Yang Terfokus Pada Pelayanan Anak Di Era Digital”, prosiding seminar nasional tahun 2018: pelayanan anak : perbesardaya kreatif pelayanan anak zaman digital. 2018; 18

${ }^{7}$ Daniel Fajar Panuntun et al., Model ibadah Sekolah Minggu Kreatif-Interaktif Bagi Generasi Alfa Di Gereja Toraja, "BIA: Jurnal Teologi dan Pendidikan Kristen Kobtekstual 2, no.2 (2019)
} 
perkembangan anak. Permainan dalam mebig merupakan permainan sederhana yang merupakan permainan wajar dilakukan oleh anak-anak pada usia tersebut. Gelombang otak yang terpapar gawai menjadikan anak-anak memiliki pola pertumbuhan visual yang mengakibatkan hasil rekaman electroence-phalograph (EEG) jauh dari range normal. Gelombang otak alfa dan beta yang jauh dari range normal pada anak-anak akan berimbas pada kehidupan anak pada masa dewasa dalam hal pengambilan keputusan maupun berpikir kreatif, sebab masa anak-anak lebih cepat menangkap apa yang dilihatnya dan dilakukannya. ${ }^{8}$

\section{Anak usia 3-5 Tahun}

\section{Perkembangan anak usia 3-5 tahun}

Dalam perkembangan anak ada beberapa aspek yang perlu dilihat yaitu karakteristik fisik diusia 3-5 tahun, anak sudah mampu menguasai gerakan tubuhnya dengan baik, di usia ini lebuh menyukai kegiatan fisik seperti berlari, memanjat dan melompat. tidak hanya mendengarkan saja, dia ingin menyentuh, menggerakkan dan merasakan, aspek sosial, masih suka bermain sendiri, tetapi lokasinya berdekatan dengan anak yang lain. Mulai memerlukan permainan bersama, tapi biasanya di dalam kelompok kecil. Aspek perkembangan emosional anak dalam usia ini bersigat egoisentrris, mereka mulai memahami penjelasan dan ikut berpartisipasi di dalam beberapa cerita. aspek kognitif, anak-anak dalam usia ini, memiliki rasa ingin tahu yang besar, kemampuan bahansanya mulai berkembang, anak dalam usia ini menggunakan fantasi dan permainan dramatis bersama. ${ }^{9}$

\section{Perkembangan Spiritual anak usia 3-5 tahun}

Secara rohani mereka mempunyai iman yang sederhana. untuk mengembangkan kerohaniannya,mereka diajar dengan contoh, sikap, teladan dan harus dimengerti bahwa pengajaran rohani dilakukan secara alami. Anak di usia ini akan berkembang bila diajari kebenaran dan pengetahuan Alkitab. Disini orang tua sangat berperan dalam perkembangan rohani anak melalui keteladanan karena anak di usia ini lebih cepat menangkapapa yang dilhatnya dan dilakukannya. Pengajaran rohani harus dilakukan secara konkret dan dihubungkan dengan kehidupan sehari-hari itu artinya anak-anak memahami apa yang diajarkan dan apa yang di praktikkan.

\footnotetext{
${ }^{8}$ Ibid

${ }^{9} \mathrm{http} / / /$ kalidanastiti-space.blogspot.com/2014/01/karakteristik-anak-usia-3-4-tahun.html?m=1
} 
Kesimpulan dan Saran

Sekolah minggu adalah wadah dimana gereja/orangtua memperlengkapai generasi penerus gereja dalam memperlengkapi anak-anak guru sekolah minggu harus mampu merancag metode pembelajaran yang sesuai dengan perkembangan anak atau sesuai dengan kebutuhannya. Anak kelas Indria (3-5 tahun) adalah masa dimana permainan masih bagian terpenting dalam perkembangan mereka. Salah satu metode yang cocok bagi mereka adalah metode Mebig Jepang dimana mebig jepang ini sendiri mengutamakan memory, bible, dan game. Penulis memberi saran kepada guru sekolah minggu digereja-gereja agar memanfaatkan metode Mebig terkhusus pada kelas indria (3-5 tahun) dalam ibadah sekolah minggu, agar anak lebih memiliki ketertarikan dalam beribadah dan diharapkan metode Mebig dapat menunjang minat beribadah anak-anak. 


\section{Daftar Pustaka}

Satya, Eka Venti,2018 “Strategi Indonesia Menghadapi Industri 4.0. ”Jurnal Info Singkat: Kajian Singkat Terhadap Isu Aktual dan Strategis. Vol , No 09.

http://Alkitab. 2017 sabda. org/

Pilland, Harry M.1984, Perkembangan Gereja Dan Penginjilan Melalui Sekolah Minggu (Bandung:Lembaga Literatur Baptis

Resource, Jurnal Pelita Zaman, Vol 4 No.1 tahun 1989(hakikat sekolah minggu untuk anak)

Panuntun, Daniel Fajar et al.2019, Model ibadah Sekolah Minggu Kreatif-Interaktif Bagi Generasi Alfa Di Gereja Toraja, "BIA: Jurnal Teologi dan Pendidikan Kristen Kobtekstual 2, no. 2

Yama, Teppei, 2018 "Pemuridan Yang Terfokus Pada Pelayanan Anak Di Era Digital”, prosiding seminar nasional tahun 2018: pelayanan anak : perbesardaya kreatif pelayanan anak zaman digital.

Daniel Fajar Panuntun et al., Model ibadah Sekolah Minggu Kreatif-Interaktif Bagi Generasi Alfa Di Gereja Toraja, "BIA: Jurnal Teologi dan Pendidikan Kristen Kobtekstual 2, no.2 (2019)

http://kalidanastiti-space.blogspot.com/2014/01/karakteristik-anak-usia-3-4-tahun.html?m=1 